\title{
Synthesis, Characterization and Pharmacological Screening of Some Substituted 1,2,3- \& 1,2,4-Triazoles
}

\author{
Y. Murti", R. Agnihotri , D. Pathak \\ Rajiv Academy for Pharmacy, Mathura
}

\begin{abstract}
The triazole nucleus is an important part of the therapeutically interesting drug candidate as antimicrobial, analgesic, anticancer, anticonvulsant and anti-inflammatory agents. Therefore, a number of 1,2,3- \& 1,2,4-triazole derivatives were synthesized. The structures of these compounds were characterized by means of FT-IR, ${ }^{1} \mathrm{H}-\mathrm{NMR}$, and elemental analysis. All the compounds were evaluated for antimicrobial activity, using Kirby-Bauer disk diffusion method and anti-inflammatory activity, using carrageenan-induced acute paw oedema method. Some of the compounds exhibited encouraging antimicrobial and anti-inflammatory results when compared with standard drugs.
\end{abstract}

Keywords Triazole, Isonicotinamide, Antimicrobial Activity, Anti-Inflammatory Activity

\section{Introduction}

Number of five membered nitrogen containing heterocycles, have turned out to be potential chemotherapeutic and pharmacotherapeutic agents. The biological profile of triazoles derivatives is very extensive $\mathrm{e}^{1-3}$. Compounds bearing a symmetrical triazole moiety are reported to show a broad spectrum of pharmacological activities such as antibacterial $^{4-7}$, antifungal ${ }^{8-11}$, antimicrobial ${ }^{12-14}$, antimycobacterial $^{15-16}$, antioxidant ${ }^{17}$, analgesic ${ }^{18,19}$, antipyretic ${ }^{20}$, anticancer $^{21-22}$, anticonvulsant ${ }^{23}$ and anti-inflammatory ${ }^{24-26}$ activities.

These observations prompted us to synthesize $N$-[5-(substitutedphenyl)-1 $H$-1,2,3-triazol-1-yl]isonicotinam ide derivatives and 4-(substituted benzylideneamino)-5pyridin-4-yl)-4H-1,2,4-triazole-3-thiol derivatives using isonicotinic acid as starting material by two different schemes (Scheme $1 \& 2$ ).

In the present paper, we describe the synthesis, characterization and antimicrobial as well as anti-inflammatory activities of the synthesized triazole derivatives. The structure assigned to compounds was substantiated by their analytical and other spectral data.

\section{Experimental}

Melting points were taken in open capillary tubes using thiels tube containing liquid paraffin and were uncorrected. Thin layer chromatography on silica gel G plates (Merck

* Corresponding author:

ymurti@gmail.com (Y. Murti)

Published online at http://journal.sapub.org/chemistry

Copyright (C) 2011 Scientific \& Academic Publishing. All Rights Reserved
Silica- $60 \mathrm{~F}_{254}$ ) was used to access the completion of the reaction and to determine the purity of the synthesized compounds. The structure of all the newly synthesized compounds were confirmed by FT-IR (Recorded on a FTIR-8400S spectrophotometer, SHIMADZU), ${ }^{1} \mathrm{H}-\mathrm{NMR}$ (Recorded on Bruker NMR spectrophotometer in deuterium-substituted DMSO form using TMS as internal standard). Elemental analysis was performed for $\mathrm{C}, \mathrm{H}$ and $\mathrm{N}$ using Perkin-Elmer Model 240C and was within $\pm 0.4 \%$ of theoretical values.

General procedure for Synthesis of $N$-[5-substituted phenyl)-1H-1,2,3-triazol-1-yl]isonicotinamide derivatives (1-5)

Isonicotinic acid hydrazide $(1.37 \mathrm{~g}, 0.01 \mathrm{~mole})$ was dissolved in absolute ethanol $(30 \mathrm{~mL})$. To the above solution, substituted benzaldehyde ( 0.01 mole) was added in the presence of few drops of glacial acetic acid and refluxed for $5 \mathrm{hrs}$. Then the resulting mixture was cooled, filtered and recrystallized from ethanol. This gives intermediate hydrazone compound, which on cyclization forms the required triazole. For cyclization freshly prepared diazomethane gas was passed into the intermediate hydrazone dissolved in 1,4-dioxane. The solution was allowed to stand for $24 \mathrm{hrs}$. so that complete cyclization take place. The product obtained was recrystallized from 1,4-dioxane. (Scheme 1)

$\mathrm{N}$-(5(4'-Chlorophenyl)-1 $\mathrm{H}$-1,2,3-triazol-1-yl)isonicotina mide (1)

Yield:74.2\%; m.p.: $276^{\circ} \mathrm{C}$; IR $(\mathrm{KBr}) v\left(\mathrm{~cm}^{-1}\right): 3328(\mathrm{NH}$ stretching), 3067 (aromatic $\mathrm{CH}$ stretching), $1664(\mathrm{C}=\mathrm{O}$ stretching), $1562(>\mathrm{C}=\mathrm{N}$ stretching), 1450 (aromatic $\mathrm{C}=\mathrm{C}$ stretching), 1334 (C-N stretching), 818 (C-Cl stretching); ${ }^{1} \mathrm{H}$ NMR $\delta(\mathrm{ppm}): 5.32$ (s, $1 \mathrm{H}, \mathrm{CH}$ of triazole), 7.64-7.85 (m, 6H, aromatic protons), $8.06(\mathrm{~m}, 2 \mathrm{H}$, aromatic protons) and 11.83 (s, $1 \mathrm{H}, \mathrm{CONH})$. 
$\mathrm{N}$-(5(3'-Hydroxyphenyl)-1 $\mathrm{H}$-1,2,3-triazol-1-yl)isonicotin amide (2)

Yield: $62.5 \%$; m.p.: $282{ }^{\circ} \mathrm{C}$; IR $(\mathrm{KBr}) v\left(\mathrm{~cm}^{-1}\right): 3448(\mathrm{OH}$ stretching), 3321 ( $\mathrm{NH}$ stretching), 3078 (aromatic $\mathrm{CH}$ stretching), 1675 ( $\mathrm{C}=\mathrm{O}$ stretching), $1554(>\mathrm{C}=\mathrm{N}$ stretching $)$, 1485 (aromatic $\mathrm{C}=\mathrm{C}$ stretching), 1342 (C-N stretching), ${ }^{1} \mathrm{H}$ NMR $\delta(\mathrm{ppm}): 3.51(\mathrm{~s}, 1 \mathrm{H}, \mathrm{OH}), 5.34(\mathrm{~s}, 1 \mathrm{H}, \mathrm{CH}$ of triazole), 7.64-7.85 (m, $6 \mathrm{H}$, aromatic protons), $8.06(\mathrm{~m}, 2 \mathrm{H}$, aromatic protons) and $11.83(\mathrm{~s}, 1 \mathrm{H}, \mathrm{CONH})$.

$N$-(5(4'-Methoxyphenyl)-1 $H$-1,2,3-triazol-1-yl)isonicotin amide (3)

Yield: $60.8 \%$; m.p.: $272{ }^{\circ} \mathrm{C}$; IR $(\mathrm{KBr}) v\left(\mathrm{~cm}^{-1}\right): 3330(\mathrm{NH}$ stretching), 3044 (aromatic $\mathrm{CH}$ stretching), 2835 (C-O-CH stretching), 1644 ( $\mathrm{C}=\mathrm{O}$ stretching), 1598 ( $>\mathrm{C}=\mathrm{N}$ stretching), 1470 (aromatic $\mathrm{C}=\mathrm{C}$ stretching), 1351 (C-N stretching); ${ }^{1} \mathrm{H}$ NMR $\delta(\mathrm{ppm}): 3.13\left(\mathrm{~s}, 3 \mathrm{H}, \mathrm{OCH}_{3}\right), 5.87(\mathrm{~s}, 1 \mathrm{H}, \mathrm{CH}$ of triazole), 7.68-8.77 (m, $8 \mathrm{H}$, aromatic protons) and $10.45(\mathrm{~s}, 1 \mathrm{H}$, CONH).

$\mathrm{N}$-(5(2'-Nitrophenyl)-1 $\mathrm{H}$-1,2,3-triazol-1-yl)isonicotinami de (4)

Yield: $66.0 \%$; m.p.: $288^{\circ} \mathrm{C}$; IR $(\mathrm{KBr}) v\left(\mathrm{~cm}^{-1}\right): 3341(\mathrm{NH}$ stretching of $\mathrm{CONH}$ ), 3019 (aromatic $\mathrm{CH}$ stretching), 1681 $(\mathrm{C}=\mathrm{O}$ stretching $), 1564 \quad(>\mathrm{C}=\mathrm{N}$ stretching $), 1530 \quad\left(\mathrm{NO}_{2}\right.$ stretching), 1429 (aromatic $\mathrm{C}=\mathrm{C}$ stretching), 1348 (C-N stretching of triazole); ${ }^{1} \mathrm{H}$ NMR $\delta(\mathrm{ppm}): 5.85(\mathrm{~s}, 1 \mathrm{H}, \mathrm{CH}$ of triazole), 7.54-7.80 (m, $8 \mathrm{H}$, aromatic $\mathrm{C}-\mathrm{H})$ and $11.02(\mathrm{~s}, 1 \mathrm{H}$, $\mathrm{CONH})$.

\section{$\mathrm{N}$-(5(4'-Dimethylaminophenyl)-1H-1,2,3-triazol-1-yl)} isonicotinamide (5)

Yield: $61.8 \%$; m.p.: $224{ }^{\circ} \mathrm{C}$; IR $(\mathrm{KBr}) v\left(\mathrm{~cm}^{-1}\right): 3320(\mathrm{NH}$ stretching), 3067 (aromatic $\mathrm{CH}$ stretching), 2978 (methyl $\mathrm{CH}$ stretching), $1667 \quad(\mathrm{C}=\mathrm{O}$ stretching), $1597 \quad(>\mathrm{C}=\mathrm{N}$ stretching), 1564 (aromatic $\mathrm{C}=\mathrm{C}$ stretching), 1353 (C-N stretching of triazole); ${ }^{1} \mathrm{H}$ NMR $\delta(\mathrm{ppm}): 3.20(\mathrm{~s}, 6 \mathrm{H}$, $\left.\mathrm{N}\left(\mathrm{CH}_{3}\right)_{2}\right), 5.58(\mathrm{~s}, 1 \mathrm{H}, \mathrm{C}-\mathrm{H}$ of triazole $), 7.59-9.28(\mathrm{~m}, 8 \mathrm{H}$, aromatic protons) and $11.67(\mathrm{~s}, 1 \mathrm{H}, \mathrm{CONH})$.

General procedure for Synthesis of 4-(substituted benzylidene amino)-5-(pyridin-4-yl)-4H-1,2,4-triazol-3thiol derivatives (6-10)

In a $500 \mathrm{~mL}$ round bottom flask isonicotinic acid hydrazide ( $13.7 \mathrm{~g}, 0.1$ mole) was dissolved in absolute ethanol $(200 \mathrm{~mL})$ containing potassium hydroxide $(11.2 \mathrm{~g}, 0.1 \mathrm{~mole})$ at room temperature and carbon disulphide $(13.17 \mathrm{~mL}, 0.21$ mole) was added in parts. This mixture was agitated for 16 hrs. and diluted with dry diethyl ether $(100 \mathrm{~mL})$. The product was filtered off and vacuum dried at $65-70^{\circ} \mathrm{C}$. The potassium dithiocarbazinate salt prepared as described above was obtained in nearly quantitative yields.

Hydrazine hydrate $(0.01$ mole, $99 \%)$ was added gradually to the potassium dithiocarbazinate salt dissolved in water $(100 \mathrm{~mL})$ with stirring and was refluxed on a water bath until the evolution of $\mathrm{H} 2 \mathrm{~S}$ gas ceased. The reaction was monitored by silica gel coated TLC. It was then cooled and carefully acidified with concentrated hydrochloric acid. The solid thus separated was filtered, washed with cold water and purified by recrystallization from ethanol to give 4-amino-5-pyridin4-yl)-4H-1,2,4-triazol-3-thiol.
In a $50 \mathrm{~mL}$ round bottom flask, solution of 4-amino-5pyridin-4-yl)-4H-1,2,4-triazol-3-thiol (1.93 g, 0.01 mole) in dimethyl formamide $(20 \mathrm{~mL})$ and few drops of glacial acetic acid was added. This mixture was reacted with various substituted benzaldehydes ( 0.01 mole) and refluxed for 7-9 hrs. The progress of reaction was monitored by TLC. The reaction mixture was cooled and the precipitate obtained was filtered, dried in vacuum and recrystallized from ethanol. (Scheme 2)

4(4'-Chlorobenzylidene amino)-5-(pyridin-4-yl)-4H-

\section{1,2,4-triazol-3-thiol (6)}

Yield: $70.1 \%$ m.p.: $202{ }^{\circ} \mathrm{C}$; IR $(\mathrm{KBr}) \vee\left(\mathrm{cm}^{-1}\right): 3013$ (aromatic $\mathrm{CH}$ stretching), 2563 (SH stretching), 1603, 1485 (aromatic C-C stretching) $1566(>\mathrm{C}=\mathrm{N}$ stretching), 1448 (aromatic $\mathrm{C}=\mathrm{C}$ stretching), 1313 (C-N stretching), $828(\mathrm{C}-\mathrm{Cl}$ stretching), 688 (C-S stretching); ${ }^{1} \mathrm{H}$ NMR $\delta$ (ppm): 6.06 (s, $1 \mathrm{H}, \mathrm{N}=\mathrm{CH}), 7.59-8.76(\mathrm{~m}, 8 \mathrm{H}$, aromatic protons) and 12.59 (s, 1H, SH).

4(3'-Hydroxybenzylidene amino)-5-(pyridin-4-yl)-4H-

\section{1,2,4-triazol-3-thiol (7)}

Yield: $65.6 \%$; m.p.: $217^{\circ} \mathrm{C}$; IR $(\mathrm{KBr}) \vee\left(\mathrm{cm}^{-1}\right): 3415(\mathrm{OH}$ stretching), 2975 (aromatic $\mathrm{CH}$ stretching), 2648 (SH stretching), 1664 (aromatic C-C stretching), $1583(>\mathrm{C}=\mathrm{N}$ stretching), 1489 (aromatic $\mathrm{C}=\mathrm{C}$ stretching), 1365 (C-N stretching), 682 (C-S stretching); ${ }^{1} \mathrm{H}$ NMR $\delta$ (ppm): 3.78 (s, $1 \mathrm{H}, \mathrm{OH}), 5.69(\mathrm{~s}, 1 \mathrm{H}, \mathrm{N}=\mathrm{CH}), 7.72-7.90(\mathrm{~m}, 4 \mathrm{H}$, aromatic protons), 8.01-8.13 (m, $4 \mathrm{H}$, aromatic protons), 12.49 (s, $1 \mathrm{H}$, $\mathrm{SH})$.

4(4'-Methoxybenzylidene amino)-5-(pyridin-4-yl)-4H1,2,4-triazol-3-thiol (8)

Yield: $68.8 \%$; m.p.: $172{ }^{\circ} \mathrm{C}$; IR $(\mathrm{KBr}) \vee\left(\mathrm{cm}^{-1}\right): 3051$ (aromatic $\mathrm{CH}$ stretching), $2872\left(\mathrm{C}-\mathrm{O}-\mathrm{CH}_{3}\right), 2621$ (SH stretching), 1606 (aromatic C-C stretching), $1571(>\mathrm{C}=\mathrm{N}$ stretching), 1468 (aromatic $\mathrm{C}=\mathrm{C}$ stretching), 1347 (C-N stretching), 678 (C-S stretching); ${ }^{1} \mathrm{H}$ NMR $\delta$ (ppm): 3.79 (s, $\left.3 \mathrm{H},-\mathrm{O}-\mathrm{CH}_{3}\right), 7.67(\mathrm{~s}, 1 \mathrm{H}, \mathrm{N}=\mathrm{CH}), 7.25-8.10(\mathrm{~m}, 8 \mathrm{H}$, aromatic protons) and $11.79(\mathrm{~s}, 1 \mathrm{H}, \mathrm{SH})$.

4(2'-Nitrobenzylidene amino)-5-(pyridin-4-yl)-4H1,2,4-triazol-3-thiol (9)

Yield: $69.8 \%$; m.p.: $222{ }^{\circ} \mathrm{C}$; IR $(\mathrm{KBr}) \vee\left(\mathrm{cm}^{-1}\right): 3033$ (aromatic C-H stretching), 2579 (SH stretching), 1609, 1585, 1452 (aromatic C-C stretching), 1589 ( $>\mathrm{C}=\mathrm{N}$ stretching), 1446 (aromatic $\mathrm{C}=\mathrm{C}$ stretching), 1353 (aromatic $-\mathrm{NO}_{2}$ stretching), 1315 (C-N stretching), 698 (C-S stretching); ${ }^{1} \mathrm{H}$ NMR $\delta(\mathrm{ppm}): 5.58 \quad(\mathrm{~s}, 1 \mathrm{H}, \mathrm{N}=\mathrm{CH}), 7.78-8.71(\mathrm{~m}, 8 \mathrm{H}$, aromatic protons) and $12.68(\mathrm{~s}, 1 \mathrm{H}, \mathrm{SH})$.

4(4'-Dimethylaminobenzylidene amino)-5-(pyridin-4yl)-4H-1,2,4-triazol-3-thiol (10)

Yield: $77.2 \%$; m.p.: $198{ }^{\circ} \mathrm{C}$; IR (KBr) $\vee\left(\mathrm{cm}^{-1}\right): 3132$ (aromatic CH stretching), 2940 (methyl $\mathrm{CH}$ stretching), 2544 ( $\mathrm{SH}$ stretching), $1573(>\mathrm{C}=\mathrm{N}$ stretching), 1473 (aromatic $\mathrm{C}=\mathrm{C}$ stretching), 1344 (C-N stretching), 671 (C-S stretching); ${ }^{1} \mathrm{H}$ NMR $\delta$ (ppm): 3.20 (s, 6H, N(CH3)2), 8.08 (s, $1 \mathrm{H}, \mathrm{N}=\mathrm{CH}), 7.59-8.78(\mathrm{~m}, 8 \mathrm{H}$, aromatic protons) and 12.32 (s, 1H, SH).

\section{Pharmacology}




\section{Antimicrobial activity}

The antimicrobial activity of the synthesized compounds (1-10) was determined in-vitro by using Kirby-Bauer disk diffusion method $^{27}$ against four bacterial strains: Bacillus subtilis (NCIM 2063), Staphylococcus aureus (NCIM 2079) (Gram-positive bacteria), Escherichia coli (ATCC 11775), Pseudomonas aeruginosa (ATCC 10145) (Gram-negative bacteria) and two fungal strains: Aspergillus niger (ATCC 16404) and Candida albians (ATCC 10231) at $100 \mu \mathrm{g} \mathrm{mL}^{-1}$ concentration. Norfloxacin and griseofulvin were used as standard drugs for antibacterial and antifungal activity respectively. Control test with solvents were performed for every assay but showed no inhibition of the microbial growth. The antimicrobial results of the synthesized compounds are reported in table 2 as zone of inhibition $(\mathrm{mm})$ against various bacterial and fungal strains respectively.

\section{Anti-inflammatory activity}

All the synthesized compounds (1-10) were also screened for anti-inflammatory activity by using carrageenan-induced acute paw oedema method 28 on rats (Wistar strain) of either sex weighing 200-300 $\mathrm{mg}$. The rats were randomly divided in to three groups; each consisted of a minimum of 6 animals. The suspensions of the newly synthesized compounds, uniformly dispersed in $2 \%$ tween- 80 were administered to test animals orally. The control groups received the same experimental handling as test groups in place of test compounds equivalent doses of vehicle alone were administered. Food and water were withdrawn during the test. Phenyl butazone was used as the standard anti-inflammatory drug.

Acute oedema in the hind paws of rat was induced by the planter injection of freshly prepared, w/v carrageenan in distilled water $(0.1 \mathrm{ml}$ of freshly prepared, w/v carrageenan in distilled water). The paw volume was measured immediately ( $0 \mathrm{hr}$ ) and after $1,2.3$ and 4 th hrs by using plethysmograph. The amount of oedema in the drug-treated groups was compared in relation to the control group with the corresponding time intervals. The percentage inhibition by the compounds was calculated according to the following formula,

$$
\text { Percentage inhibition }=100\left(1-\mathrm{V}_{\mathrm{t}} / \mathrm{V}_{\mathrm{c}}\right) \text {, }
$$

Where; Vt and Vc are the oedema volumes in the drug treated and the control groups.

The results were expressed as percentage inhibition of oedema over the untreated control group (table 3 ).

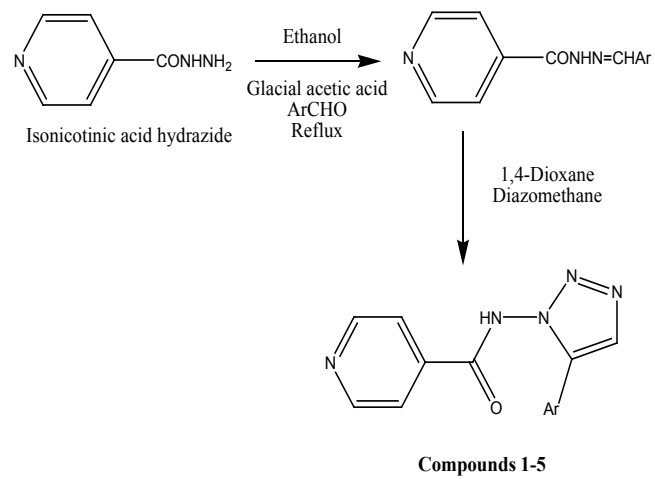

Scheme 1. 5-(Substituted phenyl)-1H-1,2,3-triazol-1-yl] isonicotinamide derivatives

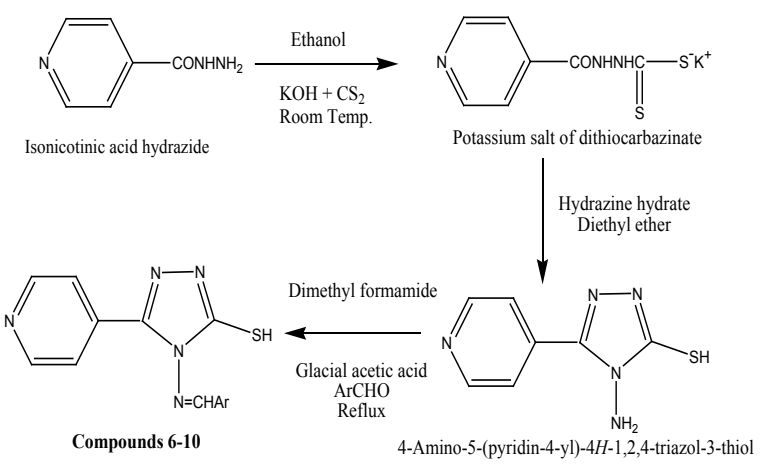

Scheme 2. 4-(Substituted benzylidene amino)-5-(pyridin-4-yl)-4H-1,2,4-tr iazol-3-thiol derivatives

Table 1. Analytical data of the synthesized compounds (1-10)

\begin{tabular}{|c|c|c|c|c|c|c|}
\hline \multirow{2}{*}{$\begin{array}{l}\text { S. } \\
\text { No. }\end{array}$} & \multirow{2}{*}{ Ar } & \multirow{2}{*}{$\begin{array}{l}\text { Mol. Formula (Mol. } \\
\text { Wt.) }\end{array}$} & \multirow{2}{*}{$\begin{array}{c}\mathbf{R}_{\mathbf{f}} \\
\text { Value* }\end{array}$} & \multicolumn{3}{|c|}{$\begin{array}{l}\text { Elemental analysis*** } \\
\text { Calcd. (Found) }\end{array}$} \\
\hline & & & & $\mathbf{C}$ & $\mathbf{H}$ & $\mathbf{N}$ \\
\hline 1 & 4'-Chlorophenyl & $\mathrm{C}_{14} \mathrm{H}_{10} \mathrm{ClN}_{5} \mathrm{O}(299)$ & 0.77 & $56.10(56.11)$ & $3.36(3.35)$ & $23.37(23.36)$ \\
\hline 2 & 3'-Hydroxyphenyl & $\mathrm{C}_{14} \mathrm{H}_{11} \mathrm{~N}_{5} \mathrm{O}_{2}(281)$ & 0.87 & $59.78(59.77)$ & $3.94(3.95)$ & $24.90(24.88)$ \\
\hline 3 & 4'-Methoxyphenyl & $\mathrm{C}_{15} \mathrm{H}_{13} \mathrm{~N}_{5} \mathrm{O}_{2}(295)$ & 0.81 & $61.01(61.03)$ & $4.44(4.42)$ & $23.72(23.70)$ \\
\hline 4 & 2'-Nitrophenyl & $\mathrm{C}_{14} \mathrm{H}_{10} \mathrm{~N}_{6} \mathrm{O}_{3}(310)$ & 0.76 & $54.20(54.22)$ & $3.25(3.23)$ & $27.09(27.10)$ \\
\hline 5 & 4'-Dimethylaminophenyl & $\mathrm{C}_{16} \mathrm{H}_{16} \mathrm{~N}_{6} \mathrm{O}(308)$ & 0.83 & $62.32(62.30)$ & $5.23(5.25)$ & $27.26(27.25)$ \\
\hline 6 & 4'-Chlorophenyl & $\mathrm{C}_{14} \mathrm{H}_{10} \mathrm{ClN}_{5} \mathrm{~S}(315)$ & 0.79 & $53.25(53.24)$ & $3.19(3.20)$ & $22.18(22.20)$ \\
\hline 7 & 3'-Hydroxyphenyl & $\mathrm{C}_{14} \mathrm{H}_{11} \mathrm{~N}_{5} \mathrm{OS}(297)$ & 0.85 & $56.55(56.57)$ & $3.73(3.71)$ & $23.55(23.54)$ \\
\hline 8 & 4'-Methoxyphenyl & $\mathrm{C}_{15} \mathrm{H}_{13} \mathrm{~N}_{5} \mathrm{OS}(311)$ & 0.75 & $57.86(57.85)$ & $4.21(4.22)$ & $22.49(22.51)$ \\
\hline 9 & 2'-Nitrophenyl & $\mathrm{C}_{14} \mathrm{H}_{10} \mathrm{~N}_{6} \mathrm{O}_{2} \mathrm{~S}(326)$ & 0.86 & $51.53(51.52)$ & $3.09(3.11)$ & $25.75(25.76)$ \\
\hline 10 & 4'-Dimethylaminophenyl & $\mathrm{C}_{16} \mathrm{H}_{16} \mathrm{~N}_{6} \mathrm{~S}(324)$ & 0.84 & $59.24(59.21)$ & $4.97(5.00)$ & $25.91(25.89)$ \\
\hline
\end{tabular}

*Solvent System: Ethyl acetate:petroleum ether $\left(40-60^{\circ} \mathrm{C}\right)$ :methanol, $3: 3: 1, \mathrm{v} / \mathrm{v}$

**The combustion analysis of compounds synthesized is within the limits of permissible errors. 
Table 2. Antimicrobial activity of synthesized compounds (1-10)

\begin{tabular}{|c|c|c|c|c|c|c|}
\hline \multirow{3}{*}{$\begin{array}{c}\text { Compd. } \\
\text { No. }\end{array}$} & \multicolumn{6}{|c|}{ Diameter of zone of inhibition at $100 \mu \mathrm{g} \mathrm{mL} \mathrm{m}^{-1}$ (in mm.) } \\
\hline & \multicolumn{4}{|c|}{ Bacterial strains } & \multicolumn{2}{|c|}{ Fungal strains } \\
\hline & B. sub. ${ }^{1}$ & S. aur. $^{2}$ & E. coli $^{3}$ & P. aeru. $^{4}$ & A. niger $^{5}$ & C. albicans $^{6}$ \\
\hline 1 & $24.82 \pm 0.58$ & $23.00 \pm 1.00$ & $22.67 \pm 0.58$ & $28.33 \pm 1.16$ & $24.00 \pm 1.00$ & $25.33 \pm 0.58$ \\
\hline 2 & $20.33 \pm 1.16$ & $18.67 \pm 0.58$ & $18.00 \pm 0.00$ & $25.33 \pm 0.58$ & $23.67 \pm 0.58$ & $24.33 \pm 1.16$ \\
\hline 3 & $22.00 \pm 1.00$ & $21.88 \pm 1.16$ & $20.67 \pm 1.16$ & $26.67 \pm 0.58$ & $22.33 \pm 0.58$ & $23.00 \pm 1.00$ \\
\hline 4 & $20.65 \pm 1.16$ & $20.67 \pm 0.58$ & $17.00 \pm 1.00$ & $19.33 \pm 0.58$ & $23.33 \pm 0.58$ & $24.67 \pm 1.16$ \\
\hline 5 & $23.00 \pm 0.00$ & $22.33 \pm 0.58$ & $22.33 \pm 0.58$ & $27.67 \pm 1.16$ & $23.67 \pm 1.16$ & $24.00 \pm 0.00$ \\
\hline 6 & $25.43 \pm 0.58$ & $23.00 \pm 1.00$ & $22.87 \pm 1.16$ & $28.00 \pm 0.58$ & $24.33 \pm 0.58$ & $25.67 \pm 0.58$ \\
\hline 7 & $20.90 \pm 0.00$ & $19.33 \pm 0.58$ & $18.67 \pm 0.58$ & $25.00 \pm 1.00$ & $23.33 \pm 0.58$ & $25.00 \pm 0.00$ \\
\hline 8 & $21.80 \pm 0.58$ & $22.10 \pm 0.58$ & $17.67 \pm 0.58$ & $18.33 \pm 0.58$ & $24.67 \pm 0.58$ & $25.33 \pm 0.58$ \\
\hline 9 & $19.09 \pm 0.58$ & $20.31 \pm 0.58$ & $19.33 \pm 1.16$ & $20.33 \pm 1.16$ & $22.00 \pm 0.00$ & $23.33 \pm 0.58$ \\
\hline 10 & $23.33 \pm 0.58$ & $22.00 \pm 0.00$ & $22.00 \pm 1.00$ & $27.00 \pm 1.00$ & $23.00 \pm 0.58$ & $23.67 \pm 0.58$ \\
\hline Norfloxacin & $26.67 \pm 0.58$ & $24.33 \pm 1.16$ & $23.33 \pm 0.58$ & $29.67 \pm 0.58$ & - & - \\
\hline Griseofulvin & - & - & - & - & $25.00 \pm 1.00$ & $26.33 \pm 0.58$ \\
\hline
\end{tabular}

All the values are in Mean \pm S.D. $(n=3)$;

1= Bacillus subtilis (NCIM 2063); 2=Staphylococcus aureus (NCIM 2079); $3=$ Escherichia coli (ATCC 11775); 4= Pseudomonas aeruginosa (ATCC 10145); $5=$ Aspergillus niger (ATCC 16404); 6= Candida albians (ATCC 10231)

Table 3. Anti-inflammatory activity of synthesized compounds (1-10)

\begin{tabular}{|c|c|c|c|c|c|c|c|c|}
\hline \multirow{2}{*}{$\begin{array}{c}\text { Compd. } \\
\text { No. }\end{array}$} & \multicolumn{4}{|c|}{ Change in paw volume (in $\mathrm{mL})$ after $( \pm \mathrm{SE})^{\#}$} & \multicolumn{4}{|c|}{ Percentage inhibition of oedema volume after } \\
\hline & $1 \mathbf{h}$ & $\mathbf{2 h}$ & 3h & 4h & $1 \mathbf{h}$ & $\mathbf{2 h}$ & 3h & 4h \\
\hline 1 & $0.77 \pm 0.02$ & $1.05 \pm 0.03$ & $1.47 \pm 0.02$ & $1.68 \pm 0.07$ & 14.8 & $17.3^{*}$ & 25.0 & $32.2 *$ \\
\hline 2 & $0.78 \pm 0.04$ & $1.06 \pm 0.03$ & $1.40 \pm 0.02$ & $1.77 \pm 0.02$ & $13.6^{*}$ & $17.8^{* *}$ & 28.6 & $33.9 *$ \\
\hline 3 & $0.81 \pm 0.03$ & $1.07 \pm 0.02$ & $1.42 \pm 0.04$ & $1.65 \pm 0.03$ & 13.5 & 16.8 & 26.4 & 31.8 \\
\hline 4 & $0.74 \pm 0.02$ & $0.93 \pm 0.04$ & $1.44 \pm 0.05$ & $1.60 \pm 0.02$ & 10.0 & 13.3 & 22.7 & $26.7 * * *$ \\
\hline 5 & $0.71 \pm 0.02$ & $1.01 \pm 0.07$ & $1.38 \pm 0.07$ & $1.58 \pm 0.00$ & $9.4^{*}$ & 10.9 & 18.9 & 20.6 \\
\hline 6 & $0.60 \pm 0.03$ & $0.81 \pm 0.02$ & $1.16 \pm 0.02$ & $1.44 \pm 0.05$ & 14.2 & $17.4 * *$ & 25.3 & $32.7 *$ \\
\hline 7 & $0.62 \pm 0.05$ & $0.85 \pm 0.02$ & $1.06 \pm 0.04$ & $1.29 \pm 0.02$ & $13.9 * * *$ & 16.9 & $27.5^{*}$ & $34.4 * *$ \\
\hline 8 & $0.61 \pm 0.02$ & $1.10 \pm 0.05$ & $1.08 \pm 0.02$ & $1.31 \pm 0.05$ & $12.9 *$ & 17.1 & 26.2 & $32.0 *$ \\
\hline 9 & $0.72 \pm 0.04$ & $0.98 \pm 0.02$ & $1.00 \pm 0.00$ & $1.45 \pm 0.06$ & 9.9 & $13.7 * *$ & 21.9 & 25.2 \\
\hline 10 & $0.77 \pm 0.03$ & $1.07 \pm 0.04$ & $1.49 \pm 0.02$ & $1.70 \pm 0.02$ & 8.7 & 11.4 & $18.7 * *$ & $19.8^{*}$ \\
\hline $\begin{array}{c}\text { Phenyl } \\
\text { butazone }\end{array}$ & $0.75 \pm 0.04$ & $0.89 \pm 0.03$ & $0.95 \pm 0.02$ & $1.10 \pm 0.03$ & $17.5 * * *$ & $22.7 * * *$ & $39.2 * * *$ & $48.0 * * *$ \\
\hline
\end{tabular}

\#=Standard error; Significance level $*=\mathrm{P}<0.05, * *=\mathrm{P}<0.01, * * *=\mathrm{P}<0.001$ compared with respective control (ANOVA followed by Dunnett's test).

\section{Result and Discussion}

The present study reports the successful synthesis of the title compounds in good yields and the reaction sequences for the synthesis are shown in Scheme $1 \& 2$. The analytical data of the compounds (1-10) were collected and are presented in table 1 and spectral data are given under compound name. The newly synthesized compounds were screened for their antimicrobial and anti-inflammatory activities and the results of screening studies are tabulated in table 2 and 3 .

The formation of triazoles was confirmed by FT-IR and ${ }^{1} \mathrm{H}-\mathrm{NMR}$ analysis. The infrared spectra of compounds (1-10) showed the characteristic absorption bands of $>\mathrm{C}=\mathrm{N}$ and $\mathrm{C}-\mathrm{N}$ of triazole ring at $1562-1598 \mathrm{~cm}^{-1}$ and $1313-1365 \mathrm{~cm}^{-1}$ respectively, which confirmed the formation of triazole ring. In the ${ }^{1} \mathrm{H}-\mathrm{NMR}$ spectra of compounds (1-5), the proton signal for the $\mathrm{CH}$ of the triazole ring was observed as a singlet between 5.32-5.87 ppm and which was absent in compounds (6-10) due to the presence of $-\mathrm{SH}$ group. The proton signal for the S-H proton on triazole ring was observed in these compounds (6-10) as a singlet at 11.79-12.68 ppm. The absence of $\mathrm{C}=\mathrm{S}, \mathrm{N}-\mathrm{H}$ and presence of S-H absorption established that the triazole ring in compound (6-10) are in thiol form.

The antimicrobial results showed that some of the newly synthesized compounds are active against the tested microbes. It can be concluded that none of the prepared compounds were superior to positive controls against various tested microbial strains, but was interesting to note that compounds 1 and 6 were very sensitive to all the tested organisms and were comparable to the standards used. Based on the structure activity relationships, it can be concluded that the presence of halogen group at 4 positions i.e. compounds 1 and 6 exhibited excellent antibacterial and antifungal activity showing importance of halogenated compounds. Presence of nitro group and methoxy group at 4 position i.e. compounds $3,4,8$ and 9 displayed good activity towards Gram positive bacteria. Compounds 2, 4, 7 and 9 displayed remarkable antifungal activity showing the importance of hydroxyl and nitro compounds. Presence of dimethyamino group at 4 position i.e. compounds 5 and 10 showed good activity against all tested microbial strains.

The anti-inflammatory activity studies indicated that compounds 1-3 and 6-8 exhibited high degree of anti -inflammatory activity. Some of the tested compounds had shown moderate to very weak anti-inflammatory activity. 
However, the anti-inflammatory activity of the tested compounds was less than that of standard drug used. Suitable molecular modification of these compounds can prove as potent antimicrobial and anti-inflammatory agents in future.

\section{ACKNOWLEDGEMENTS}

The authors are thankful to Central Institute for Research on Goats, Farah, Mathura, for providing microbial strains for antimicrobial screening. The authors are also thankful to the Head, Regional Sophisticated Instrumentation Centre (RSIC), Central Drug Research Institute (CDRI), Lucknow, India for providing elemental and spectral data.

\section{REFERENCES}

[1] Jadhav S, Rai M, Khillare L and Durrani A, Asian J. Chem., 2010, 22 (6), 4245-4248.

[2] Bekircan O and Bektas H, Molecules, 2006, 11(6), 469-477.

[3] Mathew V, Keshavayya J and Vaidya V P, Eur. J. Med. Chem., 2006, 41(9), 1048-1058.

[4] Burghate M K, Burghate S K and Berad B N, J. Indian Chem. Soc., 2008, 85, 561-565.

[5] Jayacharan E, Shivkumar B and Perumal R, Ind. J. Heterocycl. Chem., 2005, 15, 145-148.

[6] Sztanke R, Pasternak K and Jozwiak K, Biorg. Med. Chem., 2006, 14(2), 3635-3642.

[7] Prakash O P, Bhardwaj V, Kumar R and Aneja K R, Eur. J. Med. Chem., 2004, 39(12), 1073-77.

[8] Liu P, Zhu S, Xie P, Xie W, Jiang Y and Zhang D, Biorg. Med. Chem. Lett., 2008, 18, 3261-65.

[9] Lebouvier N, Pagniez F, Bault G L and Borgne M L, Biorg. Med. Chem. Lett., 2006, 17(13), 3686-3689.

[10] Magdum C S and Shirodkar P Y, J. Pharm. Res., 2005, 4(3), 48-50.
[11] Kulluraya B, Chimbalkar R and Gunaga P, Ind. J. Heterocycl. Chem., 1996, 6, 103-106.

[12] Kaplancikh Z A, Zitouni G T, Ozdemir A and Revial G, Eur. J. Med. Chem., 2008, 43, 155-159.

[13] Hipparagi S M, Majunder U K, Nargund L V G and Vinaykumar R, Ind. J. Het. chem., 2007, 16, 401-402.

[14] Iqbal R., Rama N H and Ahmed N, Ind. J. Chem., 1997, 37B, 506-509.

[15] Ganapaty S, Ramalingam P and Babu Rao C H, J. Pharm. Res. 2007, 6(1), 10-12.

[16] Kucukguzel I, Tatar E and Clercq E D, Eur. J. Med. Chem., 2007, XX, 1-12.

[17] Kamotra P, Gupta A K and Gupta R, Ind. J. Chem., 2007, 46B, 980-984.

[18] Gillani S J, Khan S, Alam O and Kumar H, Ind. J. Heterocycl. Chem., 2008, 17, 245-248.

[19] Pitucha M, Wujec M and Dobsz M, J. Chin. Chem. Soc., 2007, $54,69-70$.

[20] Grossi G,Roma G, Braccio M, Calcina F and Barocelli, Eur. J. Med. Chem., 2002, 37, 155-165.

[21] Sztanke K, Tuzimski T, Rzymowska J, Pasternak K and Szerszen M K, Eur. J. Med. Chem., 2008, 43, 404-419.

[22] Holla B S, Poojary K N, Rao B S and Shivananda B S, Eur. J. Med. Chem.,2002, 37(15), 511-517.

[23] Almasirad A, Tabatabai A and Shafiee A, Biorg. Med. Chem. Lett., 2004, 14(11), 6057- 6059.

[24] Kamotra P, Gupta A K and Gupta R, Ind. J. Chem., 2007, 46B, 980-984.

[25] Rao P S, Sudendra and Udupi R H, Ind. J. Heterocycl. Chem., 2006, 15, 291-2 92.

[26] Labanauskar L, Udrenaite E and Brukstus A, IL Farmaco, 2004, 59(12), 255-259.

[27] Bauer A W, Kirby W M, Sherris, J C and Turck M, Am. J. Clin. Path., 1966, 45, 493-496.

[28] Winter C A, Fisely E A and Nuss G W, Proc. Soc. Exp. Biol. Med., 1962; 111, 544. 